\author{
РУЖИЦА РАДОЈЧИК* \\ Филолошки факултет Универзитета у Београду \\ Београд, Србија
}

ГРАМАТИЧКО НАСЛЕБЕ БОГОЉУБА СТАНКОВИЋА

\begin{abstract}
Рад говори о доприносу професора Богољуба Станковића на пољу лингводидактике и представља покушај описа структурно-садржинских, лингвистичких и дидактичко-методичких аспеката двеју граматика руског језика за ученике основне школе у српској (српскохрватској) говорној средини. Оба граматичка приручника из 1978. и 1999. представљају важан допринос њихових аутора Богољуба Станковића и Љубице Несторов у конципирању дидактичких граматика руског језика по функционалном моделу.
\end{abstract}

Кључне речи: лингводидактика, граматика, структура, садржај, функционални принцип.

Међу еминентнијим представницима српске лингвистичке русистике друге половине XX века свакако се издваја лик проф. др Богољуба Станковића, прегаоца чији се допринос карактерише разноврсношћу идеја и интересовања, као и значајним резултатима у оквиру ове научне дисциплине. Био је настављач теоријских и практичних достигнућа својих славних претходника и учитеља. Као иноватор и неуморни творац, креативно је и оригинално реализовао нове идеје, развијајући тиме већ постојеће резултате у овој области.

Пре него што приступимо анализи наслеђа које је Богољуб Станковић оставио на лингводидактичком пољу свога рада, у области која се односи на дидактичке граматике руског језика у српској говорној средини, навешћемо најпре неке од релевантнијих биографских података.

Богољуб Станковић рођен је у Доњој Коритници код Беле Паланке, 9. априла 1938. године. После завршене основне школе у родном месту, гимназију наставља у Белој Паланци и Нишу, где је матурирао 1956. године, када уписује Вишу педагошку школу коју завршава две године касније. Као наставник српскохрватског и руског језика наставља школовање

*rudbrudr@gmail.com 
на Филолошком факултету у Београду, где је 1968. године дипломирао на групи за руски језик и књижевност. На истом факултету одбранио је магистарски рад 1972. године, а 1977. постаје доктор лингвистичких наука. Његова дисертација под насловом Иниеерференција у йреgикайским

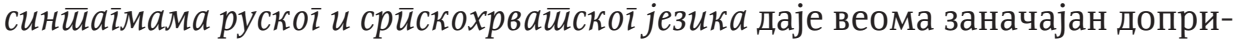
нос конфронтативним проучавањима руског и српског језика. Од 1969. до 2003. радио је на Одсеку, потом Катедри за славистику београдског Филолошког факултета, где 1988. постаје редовни професор. На основним студијама предавао је Методику наставе руског језика, Синтаксу руског језика са основама стилистике, Конфронтациону анализу руског и српскохрватског језика, док је на постдипломским студијама држао предавања из Савремене лингвистичке русистике. Обављао је и дужност управника Одсека за славистику. После пензионисања, наредних осам година радио је са истом енергијом и ентузијазмом, оставивши неизбрисив траг на пољу српске русистике и славистике.

Изненада нас је напустио 1. августа 2011. године.

Из богатог библиографског опуса Богољуба Станковића одлучили смо да издвојимо две граматике руског језика за основну школу, које су настале у коауторству са Љубицом Несторов.

Конципирање дидактичких граматика једно је од релевантнијих подручја теорије уџбеника страних језика. За наставу граматике руског језика у основној и средњој школи потребно је најпре имати у виду одлике руског језика као наставног предмета, те сходно томе и његов циљ који подразумева овладавање говорним способностима и практичну употребу језика. Да би се овај циљ постигао, настава укључује и стицање граматичких знања из фонетике, морфологије, синтаксе, стилистике. Граматички приручник стога врши функцију помоћног, али веома важног наставног средства у овладавању овим знањима, те на метаплану најчешће чини део уџбеничког комплета.

Говорећи о граматичком приручнику аутора Љубице Несторов и Богољуба Станковића, покушаћемо да опишемо лингвистичке и дидактичко-методичке аспекте ове граматике за потребе ученика основне школе који су носиоци српског језика, са освртом на начин одабира и организације лексичког и граматичког материјала.

Грамайика рускої језика: за основну школу из 1978. могла би се сматрати првим основношколским граматичким приручником руског језика на српскохрватском говорном подручју који је обликован по доминирајућем функционалном принципу. Имала је осамнаест издања од 1978. до 1994. године. По својој метаструктури она представља део уџбеничког комплета за више разреде основне школе. На нивоу макроструктуре организована је у три поглавља: I Изговор, читање и писање 
(с. 50-30); II Реченице и облици речи (с. 31-145); III Преглед врста речи са лексичким минимумом (с. 147-176). На микроплану састоји се од 139 параграфа који су инкорпорирани у 9 поднаслова (одељака), на 176 страница (укупан број страница са прегледом садржаја износи 180). Распоред сегмената књиге дат је следећим редоследом: Предговор (с. 3-4) са кратким приказом условних сликовних знакова у функцији оријентације и упућивања на граматички материјал који се обрађује од VI-VIII разреда (за сваки понаособ). Исказивање носиоца радње или стања (с. 33-35) обухвата параграфе 27-30. Исказивање радње (с. 36-56) обрађују параграфи 31-44. Исказивање лица или предмета обухваћеног радњом (с. 56-78) односи се на параграфе 45-62. Исказивање својства лица или предмета (с. 79-97) дато је у параграфима 63-76. Начин, оруђе, средство (с. 97-100) обрађени су у параграфима 77-80. Исказивање односа у простору (с. 100-122) изложено је у парграфима 81-95. Исказивање временских односа (с. 122-133) обрађено је у параграфима 96-104. Намена, намера и циљ радње (с. 134-139) обухвата параграфе 105-108. Узрочни односи (с. 140-145) обрађени су у параграфима 109-113. Поглавље I (Изговор, читање и писање) не садржи одељке са поднасловима, већ је распоређено по параграфима од 1 до 22. На исти начин представљено је поглавље III (Преглед врста речи са лексичким минимумом), кроз параграфе 114 до 139. На крају књиге налази се Садржај (с. 177-180). У циљу усвајања обрађене материје, после сваке целине следе вежбања.

Ова дидактичка граматика усклађена је са прописаним наставним планом и програмом и налази се у корелацији са структуром наставног процеса, чиме задовољава свој праксеометодички аспект. У Предговору се истиче условљеност концепције овог приручника новим Наставним програмом руског језика за основну школу. Новина се у основи односи на приступ у начину излагања, који полази од смисла преко синтаксичких модела до облика речи и конкретних исказа. Увођење новог материјала почиње презентовањем примера, после чега се уобличује правило, што је одлика индуктивног методолошког приступа. За разлику од традиционалног модела дотадашњих граматика руског језика, материјал је изложен кроз говорне структуре, презентовањем језичких средстава за изражавање семантичких категорија, према функционалном моделу: у смеру од значења ка синтаксичким моделима и од синтаксичких модела ка облицима речи и конкретним комуникативним исказима. Применом овог метода граматички материјал се не презентује апстраховано од његове употребе, већ се давањем појединачних примера поступно долази до граматичких правила. Ова дидактичка граматика усклађена је са појединачним уџбеницима за сваки разред (од VI до VIII), те на нивоу 
своје метаструктуре остварује чврсту повезаност са уџбеничким комплетима за више разреде основне школе.

Конфронтациони метод присутан је у сталном поређењу са српским (српскохрватским) језиком, упућивањем на идентичности, сличности и разлике између одређених категорија у оба језика, што је од посебне важности за спречавање интерференције, односно за стимулисање фацилитације у процесу усвајања руског као генетски и типолошки сродног језика.

Апаратуром огранизације усвајања постиже се ефикаснија активност ученика у овладавању граматичким материјалом. Питања, задаци и вежбања уз сваки параграф подстичу синтетизовање и систематизацију усвојеног градива. Терминологија је прилагођена узрасту корисника. Градиво је обједињено по целинама, распоређено по разредима, у виду интегрисаних целина. Посебним графичким ознакама издваја се градиво за поједине разреде.

Преглед врста речи са лексичким минимумом кроз парадигме дат је у последњем одељку, пошто је претходно усвојена употреба тих језичких средстава у оквиру категоријалних значења. Изостала је парадигма именица средњег рода: время, имя, знамя, што је од стране истих аутора касније унето у Грамайику из 1999. године. У оквиру II одељка презентоване су сличности и разлике у структури руске и српске реченице при изражавању идентичног садржаја (значења).

Функционални модел заступљен је у оквиру прегледа средстава свих језичких нивоа за изражавање различитих функција и значења, што подразумева језичка средства за изражавање носиоца радње или стања, објекта, оруђа, средства, односа у простору, временских односа, значења намене, намере, циља, узрока. Сходно томе, глаголи желать, хотеть, мочь, стараться обрађују се у оквиру параграфа Изражавање моіууности и жеље gа се врии нека раgюа, конструкције мне страшно, мне весело, мне хочется у оквиру параграфа Изражавање оgноса ирема pagњu, конструкције са предикативима нужно, наgо, необхоgимо, pag, у

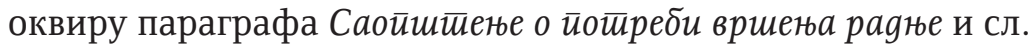

Селекција лексичког материјала такође је усклађена са предвиђеним потребним знањима ученика основне школе, како оних који су руски језик учили као први страни од петог разреда, тако и оних који су га почели учити као други страни језик од трећег разреда, са два часа недељно током свих шест година учења, до краја осмог разреда. За разлику од већег броја граматичких приручника, у овоме се руска азбука не презентује на самом почетку књиге, већ на 29. страници, после основних информација о самогласничком и сугласничком систему руског језика и најосновнијим правилима писања неких гласова. Руска азбука 
представљена је у виду табеле која садржи писану и штампану варијанту слова, као и њихове називе.

Поменули смо да је апаратура оријентације обезбеђена условним знацима, са упућивањем. У VI разреду обрађују се параграфи обележени знаком „риба”, у VII разреду обрађују се параграфи обележени знаком „цвет”, док се у VIII разреду обнављају параграфи са знацима „риба” и „цвет”, а обрађују се они обележени знаком „пиле” („птичица”). Овако организована апаратура оријентације чини део видно заступљеног илустративног материјала. Кад је реч о сликовном материјалу, у књизи преовлађују црно-бели цртежи, док се неколико обојених налази уз вежбања за усвајање назива боја у руском језику. Укупно их има 105. У одељку о глаголима кретања са префиксима по- и при- налази се девет цртежа који илуструју ситуације са значењима ових глагола. Такође, у вежбањима за усвајање глагола кретања дати су илустративни цртежи, а вежбање захтева одабир/убацивање одговарајућих глагола у складу са датим илустрованим ситуацијама. Изражавање времена према сату увежбава се помоћу три нацртана часовника према којима се од ученика захтева да на руском језику одговоре на питање „колико је сати”.

Присутни су табеларни прегледи лексичког и граматичког материјала. Тако је облик инфинитива представљен табелом у којој су две колоне посвећене несвршеном и свршеном виду глагола, а у трећу колону издвојени су инфинитивни суфикси $-m b,-m u,-u b$. Лични глаголски облици такође су презентовани табеларно, као и парадигма личних заменица и основне информације о категорији падежа.

Најчешћи типови вежбања садрже следеће инструкције: „изговорите”, „упоредите изговор”, „прочитајте текст”, прочитајте правилно”, „прочитајте стихове”, „прочитајте и подвуците”, „прочитајте и препишите”, „препишите текст”, „унесите изостављене речи”, „допуните реченице према цртежима”, „напишите на руском језику”, „одговорите на питања", „поставите питања на истакнуте речи”, „преведите на руски језик”, „преведите на српски језик”, „објасните”, „испричајте”. Пред ученицима се налазе задаци за решавање на основу задатих елемената. То су најчешће обрасци, граматички модели, табеларни прегледи граматичких форми на лексичком, синтагматском или синтаксичком нивоу. Теоријско-спознајне текстове ученици треба да прочитају или препишу; граматичке појаве треба да уоче, упореде, меморишу, објасне, а понекад и без помоћи наставника изведу своје закључке. Тежиште се ставља на усвајање формалних морфосинтаксичких карактеристика исказа. Инструкције су дате у другом лицу множине императива. Скренули бисмо пажњу на једнообразност ових инструкција, претпостављајући да су могле бити разноврсније формулисане, у циљу подстицања активности, мотивације за рад и креативност ученика приликом израде вежбања. 
Међутим, с обзиром на разноврсност представљених типова вежбања, а посебно имајући у виду приложене илустрације, ученицима се у великој мери одвраћа пажња од стереотипних инструкција. Цртежи подстичу самосталност у осмишљавању ситуација и њиховог повезивања са језичким материјалом предвиђеним за усвајање. Са друге стране, захтев (инструкција, налог) у форми императива није непознат ученицима, с обзиром на постојање сличних инструкција у уџбеницима других наставних предмета (нпр. „израчунајте”, „решите задатак”, „научите”, „запамтите” „измерите”, „нацртајте”, „отпевајте”), те овај клише не би требало да утиче на смањивање мотивационе улоге вежбања. Ипак треба нагласити да ефикасност у изради вежбања и повећање мотивације код ученика подстичу управо инструкције које су креативно формулисане, на шта скрећу пажњу Пасов (Пассов 1989: 83-84), Бим (1977: 273), Кончаревић (2002: 176).

Вежбања за усвајање изговора представљена су инструкцијама: „Прочитајте текст и подвуците речи”, „Сваки ред препишите по два пута. Док пишете, пажљиво изговарајте речи", „Прочитајте загонетку. Трудите се да вам изговор буде што мекши”, „Прочитајте стихове”, „Подвуците сугласнике који се не читају онако како су написан".

Основна ортографска правила увежбавају се најчешће уношењем изостављених графема. Аутодиктат је мање заступљен у овом граматичком приручнику.

Материјал који се односи на морфологију усваја се помоћу неколико типова вежбања, од којих смо неке већ поменули: уношење изостављене речи и њено постављање у одговарајући облик у оквиру реченице, одговори на питања постављена на српском језику у вези са теоријско-спознајним текстовима који садрже основне информације и правила, трансформација једног облика у други без већих измена у реченичној структури, превођење краћих реченица на српски или руски језик, допуна реченице према датом цртежу. Од ученика се у вежбањима тражи и да објасне неку појаву или је упореде са српским језиком.

Још један тип вежбања налаже ученицима да граматички обликују дату реч. Захтеви за оваква вежбања најчешће гласе „Следеће реченице напишите у множини”, „Образујте све облике прошлог времена од следећих глагола”, „Следеће реченице напишите у прошлом времену”.

За старије разреде дата су комбинована вежбања са одговорима на питања и превођењем на руски језик.

На крају књиге дата су вежбања која представљају рекапитулацију комплетног граматичког градива обрађеног од VI до VIII разреда, као и списак именичких, придевских, глаголских и прилошких лексема, које представљају минимум за усвајање у основној школи. Овај лексички ми- 
нимум обухвата око 550 именица сва три рода, као и 224 придева, 373 глагола и 180 прилога. Укупно око 1335 лексема.

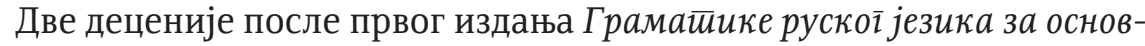
ну школу, исти аутори издају новију верзију овог граматичког приручника као посебно, ново издање, усклађено са изменама у плановима и програмима за учење руског језика у вишим разредима основне школе. На метаплану Грамайика рускої језика за основну школу из 1999. године, као и претходни приручник истих аутора, чини део уџбеничког комплета заједно са Реиником. ${ }^{1}$

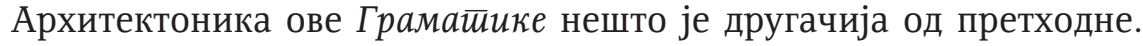
По својој макроструктури граматички материјал је подељен на три поглавља и један додатак: I Гласови и слова (с. 11-47) обухвата параграфе 1-29. II Врсте речи и облици (с. 51-114) обухвата параграфе 30-77. III Реченице и смисаони односи у њима (с. 117-267) обухвата параграфе 78-167. Додатак се налази на страницама 271-312. Организација микроструктуре такође се разликује у односу на претходни граматички приручник, мада са аспекта лингвистичког садржаја не постоје битне разлике. У оквиру три поглавља садржано је 19 одељака, што је за десет више од претходног граматичког приручника.

Уместо 211 параграфа, колико је било у претходном, овај граматички приручник садржи 167 параграфа, али на већем броју страница. Од 320 страница, 267 је посвећено презентовању граматичког материја-

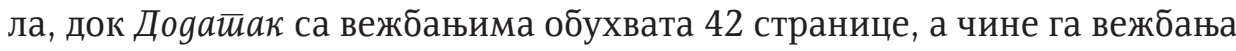
конципирана као Контиролни заgащ, у којима ученици могу проверити ниво усвојености граматичког материјала. Подељени су у три круга, са укупно 36 задатака на 22 странице (с. 271-292). Решења задатака за сва три круга изложена су на 20 страница (с. 293-312). Грамайика садржи табеле и илустративни материјал, који има за циљ визуализацију ситуација у којима се одређени граматички модели примењују у комуникацији.

Ради постизања комуникативне и лингвистичке компетенције која је усклађена са циљевима наставе за сваки конкретни разред, са њеним најбитнијим облицима (говорење, разумевање, писање, рецептивно и

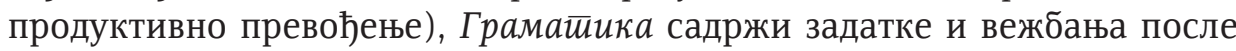
сваког прараграфа.

${ }^{1}$ Библиографију Богољуба Станковића чине и школски речници: Речник рускої језика за основну школу из 1979. године, који је до 1998. доживео једанаест издања, затим Школски руско-сритскохрвайски речник : среgюи ниво уиења из 1983. године и Школски руско-срйски речник : среgњи ниво учења из 1992. године, са још два издања из 1995. и 1998. 
И ова граматика израђена је по функционалном принципу. Граматичка правила нису дата као посебне изоловане дефиниције, већ се, као и до сада, полази од већ усвојених конструкција, да би се поступно дошло до дефиниција и закључака који се односе на фонетска, правописна, морфолошка и синтаксичка правила.

Конфронтационим методом инсистира се на идентичностима, сличностима и разликама у руском и српском језику.

За разлику од претходног граматичког приручника, називи граматичких јединица дати су на српском и руском језику.

На почетку се обрађује фонетика руског језика, уз правила изговора и писања у поређењу са српским. У овом приручнику азбука је дата непосредно пре првог параграфа (Гласови - Звуки).

У оквиру другог дела, од 30. до 77. параграфа, обрађене су именице са указивањем на разлике у роду руских и српских именица, чиме се примењује диференцијални принцип. Затим се обрађују заменице, придеви, бројеви (основни и редни), глаголи, глаголски придеви, глаголски прилози, прилози, предлози, везници, речце, узвици. Од 88. до 94. странице издвојено је преко 350 глагола које треба усвојити у основној школи.

У трећем поглављу, од 78. до 167. параграфа дата је класификација реченица према циљу и карактеру исказа. По овом критеријуму реченице су подељене на наративне, упитне, узвичне, уз одговарајуће руске термине. Класификација реченица по структури извршена је према реченичним члановима. Подељене су на једночлане и двочлане просте реченице, затим на просте непроширене, просте проширене и сложене реченице, што чини разлику у односу на претходни приручник.

Граматички материјал који је у краћим теоријско-спознајним текстовима кроз дефиниције и табеле дат у другом поглављу усваја се и примењује на нивоу реченице, у оквиру вежбања и задатака. Треће поглавље садржи материјал који је дат у другом, централном делу претходног приручника.

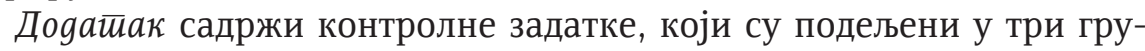
пе, после чега у посебном одељку следе њихова решења. Типови вежбања првенствено обухватају вежбе активизације различите граматичке грађе, према степену тежине, начину израде, комуникативној усмерености. Преовлађују вежбе супституције, трансформације и граматичка парафраза. Вежбања имају за циљ постизање спонтаног усвајања граматичког градива, без инсистирања на усвајању правила одвојених од њихове примене у комуникацији.

У параграфу 37 на страници 62 обрађују се именице средњег рода на -мя и именица guтя, које нису обрађене у претходној Граматиии. У напомени су дате специфичности појединих именица на -мя. 
Заменице су подељене на осам група: личне, присвојне, показне, упитне, односне, одричне, одређене, неодређене, са српским и руским називима. Представљене су табеларним прегледом, свака заменица посебно. Аутори сугеришу ученицима проверу њиховог значења у речнику.

Придеви су класификовани по значењу. Основна подела извршена је на односне и описне. Односни се даље деле на присвојне, градивне и придеве за означавање временских и просторних односа. Парадигма је табеларно представљена. Списак придева које треба усвојити у основној школи обухвата око 220 придевских лексема.

Конгруенција основних бројева са именицама и придевима није представљена издвојено. Редни бројеви дати су у виду списка и табеле, а за образац су узети первый и второй.

Облике глагола аутори разврставају у четири групе: инфинитив, лични глаголски облици (садашње прошло, будуће време, заповедни начин, потенцијал), глаголски придеви и глаголски прилози. Ученици се упознају са основним информацијама о глаголском виду. Списак глагола које треба усвојити у основној школи садржи око 370 глаголских лексема. Поједини глаголи дати су у облику инфинитива, првог и другог лица једнине и трећег лица множине презента/простог будућег времена, ради лакшег уочавања инфинитивне и презентске основе. Сугласничке алтернације у презенту и футуру посебно су издвојене.

Експлицитно је представљено конфронтирање глаголске рекције у руском и српскохрватском језику под насловом Нейоgygарање рекиија руских и срйских їлаі̄ола. Леву колону овог списка чине руски глаголи, класификовани према падежима рекцијске допуне. У десној колони налазе се српскохрватски еквиваленти са одговарајућим рекцијским допунама.

Прилози су дати у виду списка од 190 прилошких лексема које треба усвојити у основној школи.

Предлози су такође табеларно приказани у три колоне: прва носи

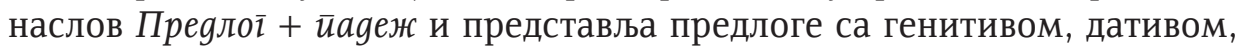
акузативом, инструменталом и локативом; средња колона носи наслов Шӣа исказује? Она пружа основна објашњења значења предлошко-падежних конструкција; у десној колони (Примери) дате су синтагме у функцији илустрације употребе предлога.

Класификација реченице извршена је према циљу и карактеру исказа. Ово поглавље садржи нешто више теоријско-спознајних текстова од претходних. Типови реченица објашњени су примерима. Сложене реченице уводе се на 119. страници у оквиру параграфа 80, објашњењем да се „две или више простих реченица могу објединити, или се, пак, део просте реченице може развијеније исказати читавом реченицом". Даље 
се ученици упознају са односима који се исказују у реченици, што је заправо чинило централни део претходне Грамайике.

Када је реч о вежбањима и илустрацијама, уочавамо да је извесни број поновљен из претходног граматичког приручника.

Аутори често упућују на коришћење речника, што се уочава у захтевима постављених задатака: „Читајући именице наведене у претходној табели, утврдите да ли знате њихово значење. Уколико нисте сигурни, значење именица проверите у школском речнику." Понеки задаци налажу писање облика множине појединих именица. Аутори упућују на презентоване табеле, ради самосталне провере урађеног задатка.

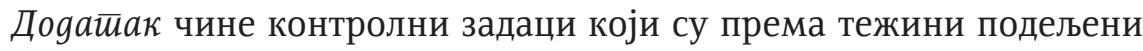
на кругове. Први круг има 40 вежбања, други и трећи круг садрже по 36 задатака, који, између осталог, подразумевају одговоре на питања и самостално формулисање неких правила.

Адвербијални односи у вежбањима усвајају се методом трансформације са нивоа синтагме (предлошко-падежних конструкција) на ниво зависносложене адвербијалне реченице.

Ради самосталне провере знања, ученици на крају књиге стичу увид у решења задатака. На овај начин пружа им се могућност растерећеног приступа решавању задатака за усвајање, обнављање и утврђивање граматичког материјала, што такође доприноси објективном самооцењивању и индивидуалној процени степена стеченог знања из области лексике и граматике руског језика.

С обзиром на карактеристике узраста корисника којима је намењена, Грамайика рускої језика за основну школу из 1999. конципирана је у складу са психолошким, лингводидактичким и лингвистичким начелима. Заступљеност матерњег српског језика неопходна је ради спречавања интерференције, односно подстицања фацилитације.

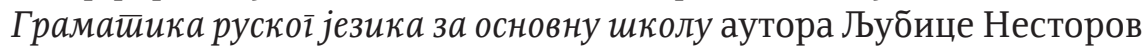
и Богољуба Станковић представља саставни део три уџбеничка комплета и следи принципе карактеристичне за системско-структурни и функ-

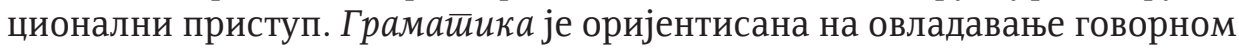
делатношћу у свим видовима, те се стога може препоручити и старијим корисницима, као основно или помоћно средство за учење руског језика, посеб́но имајући у виду табеларне прегледе и систем вежбања која поступно и прегледно презентују и систематизују садржај овог граматичког приручника.

Поред дидактичке граматике за основну школу аутора Јелице Дреновац (Грамайика руской језика за вище разреgе основне школе) из 1971.

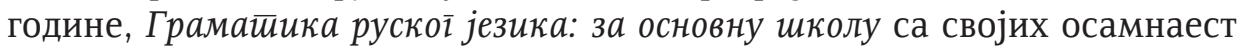

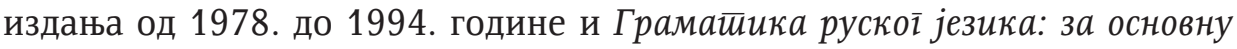
школу са своја три издања у временском интервалу од 1999. до 2004. 
представљају једине дидактичке граматике руског језика, настале у другој половини XX века, које су експлицитно намењене ученицима основне школе у српској (српскохрватској) говорној средини.

Узимајући у обзир активност Богољуба Станковића на ширем плану, у оквиру лингвистичке русистике, сматрамо да његово ангажовање на пољу лингводидактике и граматичко наслеђе које је за собом оставио овај неуморни прегалац завређују пажњу не само због бројних генерација које су своја прва знања из граматике руског језика стицале управо из ових граматичких приручника, већ и због важности овог сегмента његовог рада у српској русистици. У овој јубиларној 140-ој години постојања Катедре за славистику београдског Филолошког факултета желели смо да подсетимо да је Богољуб Станковић, као настављач теоријског и практичног наслеђа својих претходника и учитеља, дао важан допринос очувању традиција српске русистике, популаризацији руског језика у нашој средини, као и његовом очувању у настави, како у основним, тако и у средњим школама.

\section{ЛИТЕРАТУРА}

Бим, И. Л., Метоgика обучения иностранным языкам как наука и проблемь школьного учебника, Опыт системно-структурного анализа, Москва, 1977. 273.

Буњак, П., 50. скуй слависйа у знаку сећања на Боїољуба Сйанковића, Славистика XVI (2012) - 61-65.

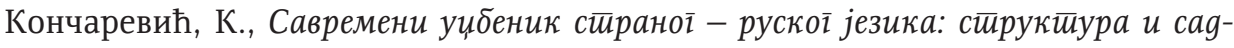
ржај, Београд, 2002. 176.

Несторов Љубица, Станковић Богољуб, Грамайика рускої језика за основну школу. Београд, 1978.

Несторов Љубица, Станковић Богољуб, Грамайика рускої језика за основну школу. Београд, 1999.

Пассов, Е. И., Основы коммуникативной метояики обуиения иноязыиному общению, Русский язык, Москва, 1989. 83-84. 


\title{
Ruzica Radojcic
}

\section{GRAMMATICAL LEGACY OF BOGOLJUB STANKOVIC}

\begin{abstract}
Summary
The paper deals with the contribution of Prof. Bogoljub Stankovic in the field of linguo-didactics and attempts to describe structural and content as well as linguo-didactic and methodical aspects of two Russian language grammar books for elementary school students in the Serbian (Serbo-Croatian) linguistic community. Both 1978 and 1999 grammar books represent an important contribution of their authors, Bogoljub Stankovic and Ljubica Nestorov, to the conception of didactic grammar books of the Russian language according to the functional model. Key words: linquo-didactics, grammar, structure, content, functional approach.
\end{abstract}

